\title{
PENGAPLIKASIAN TEORI DOUBLE MOVEMENT PADA HUKUM 'IDDAH UNTUK LAKI-LAKI
}

\author{
Ahmad Ali Masyhuda -1 \\ UIN Sunan Kalijaga

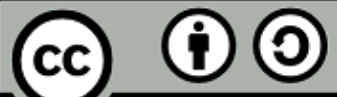 \\ BY SA
}

DOI: http://dx.doi.org/10.33603/hermeneutika.v3i2

Diterima: 3 November 2019; Direvisi: 20 Desember 2019; Dipublikasikan: Februari 2020

\begin{abstract}
Abstrak: 'iddah adalah bentuk masa penantian bagi seorang wanita untuk melakukan pernikahan lagi setelah berpisah dengan suaminya akibat cerai hidup maupun cerai mati. Hukum 'iddah untuk perempuan sudah dijelaskan dalam al-Qur'an. Akan tetapi, seiring berkembangnya zaman banyak konsep-konsep baru muncul. Hal ini mengakibatkan suatu problem yang menjadikan pertanyaan, apakah laki-laki harus melakukan 'iddah layaknya seorang wanita. Untuk menjawab persoalan ini diperlukan suatu kajian khusus yang membahas mengenai hal ini. dalam hal ini perlu penafsiran yang menggunakana metode hermeneutika al-Qur'an. Salah satu bentuk hermeneutika al-Qur'an adalah teori double movement yang digagas oleh fazlur Rahman. Dengan bantuan teori ini diharapkan bisa menjawab pertanyaan yang mempertanyakan, apakah laki-laki juga harus ikut 'iddah.
\end{abstract}

Kata kunci: 'iddah, laki-laki, double movement, penafsiran

\footnotetext{
${ }^{1}$ Ahmad Ali Masyhudal masyhuda22@gmail.com
} 


\section{PENDAHULUAN}

Perbincangan mengenai 'iddah yang merupakan persoalan yang dikhususkan pada seorang wanita tentunya sedikit banyak akan melibatkan konsep gender. Gender merupakan sebuah konsep yang muncul di zaman moderen ini untuk mengangkat drajat wanita, agar porsi di ranah publik bisa setara dengan laki-laki. Penafsiran-penafsiran ulama moderen terhadap al-Qur'an juga tidak luput akan memaskukan kosep gender, agar tidak adanya deskriminasi terhadap wanita pada sebuah penafsiran. Salah satu yang menjadikan gender sebagai dasar pijakan untuk menafsiri al-Qur'an adalah Aminah Wadud. ${ }^{1}$

Salah satu penafsiran tentang 'iddah yang membacanya dengan kaca mata gender adalah Deza Emira. Dia mengkomparasikan penentuan hukum 'iddah antara analisa dengan maqasid al-syari'ah dan gender. ${ }^{2}$

Pembahasan mengenai 'iddah sudah banyak yang telah membahasnya, baik itu dari segi macam-macamnya, KPI (Kompilasi Hukum Islam) maupun membacanya dalam konsep gender. Pembacaan 'iddah dengan melalui kacamata gender memang sudah banyak dilakukan dengan wanita sebagai pelaku yang melaksanakannya, yang mana gunanya untuk melihat bagaimana seharusnya 'iddah yang dilakukan di zaman moderen. Akan tetapi, pembacaan 'iddah yang sebagai pelakunya adalah laki-laki tidak banyak melakukannya.

Dari berbagai penelitian yang telah ada penelitian ini diposisikan sebagai penelitian yang melihat hukum iddah untuk diberlakukan pada laki-laki. Yang menjadi persoalan adalah bisakah masa 'iddah

\footnotetext{
${ }^{1}$ Lihat Amina Wadud, Perempuan di dalam al-Qur'an, (Bandung: Pustaka, 1994).

2 Lihat Deza Emira, Komparasi Analisis Maqasid Syariah dan Kesetaraan Gender Tentang Hukum 'Iddah, skaripsi (Jakarta: UIN Syarif Hidayatullah, 2016).
}

diberlakukan pada laki-laki di zaman moderen. Yang mana kondisi sosial antara zaman sekarang dan zaman turunya ayat telah berbeda.

Untuk melihat apakah seorang lakilaki juga harus melakukan 'iddah layaknya perempuan, di sini perlu dilihat dasar pokok atau ayat al-Qur'an yang menyuruh perempuan untuk 'iddah. Firman Allah:

"Wanita-wanita yang ditalak handaklah menahan diri (menunggu) tiga kali quru'. Tidak boleh mereka menyembunyikan apa yang diciptakan Allah dalam rahimnya, jika mereka beriman kepada Allah dan hari akhirat. Dan suamisuaminya berhak merujukinya dalam masa menanti itu, jika mereka (para suami) menghendaki ishlah. Dan para wanita mempunyai hak yang seimbang dengan kewajibannya menurut cara yang ma'ruf. Akan tetapi para suami, mempunyai satu tingkatan kelebihan daripada isterinya. Dan Allah Maha Perkasa lagi Maha Bijaksana." Q.S. al-Baqarah : 228).

Dari ayat di atas dalam penerapan pada laki-laki perlu suatu teori khusus. Dalam hal ini penulis mengambil teori baru dalam dunia al-Qur'an yakni hermeneutika. Meski dikalangan ulama' masih diperdebatkan pembolehan memahami ayat al-Qur'an menggunkan pendekatan hermeneutika.

Salah satu cakupan teori yang tergolong dalam pendekatan hermeneutika adalah teori double movement. Dengan menggunakan teori ini, ditujukan agar bisa memahami ayat al-Qur'an yang menerangkan 'iddah untuk diterapkan pada laki-laki.

Setelah mengetahuai latar belakang masalah pada penelitian ini, penulis memetakan rumusan maslah yang nantinya akan dijawab pada pembahasan. Pertanyaan yang muncul adalah sebagai berikut; siapa mencetuskan teori double movement dan apa yang melatarbelakangi munculnya teori ini? Bagaiamana epistimologi dari double movement? Bagaiamana ayat yang 
menjelaskan mengenai 'iddah diterapkan pada laki-laki dengan menggunakan pendektan teori double movement?

\section{METODE PENELITIAN}

Metode penelitian pada dasarnya adalah bagaimana seorang peneliti mengungkapkan sebuah cara yang diatur secara sistematis, logis, rasional, dan terarah tentang pekerjaan sebelum melakukan penelitian. Ketika sudah mengumpulkan data, dengan adanya metode ini dapat menjawab secara ilmiah dari perumusan masalah (problem akademik). ${ }^{3}$

Metode yang dimaksud guna untuk mencapai tujuan dari hasil penelitian secara optimal. Metode ini meliputi cara jenis pendekatan yang ditempuh dalam melaksanakan penelitian. ${ }^{4}$ Adapun, langkalangka yang digunakan peneliti dalam tulisan ini adalah sebagai berikut:

Pertama, data yang akan digunakan dalam penelitian ini semuanya berupa refrensi literature. Adapun untuk rujukan utama atau sumber primer yang digunakan adalah bukunya rafzlur rahman yang menjelaskan teori double movement, seperti, buku islam dan modernitas. Selanjutnya, yakni ayat al-Qur'an yang menjelaskan mengenai 'iddah terkhusus pada surat alBaqarah ayat 228.

Untuk membantu penelitian ini, juga dibutuhkana sumber yang berupa sumber skunder. Sumber yang menjadi penyokong tambahan agar bisa membantu penelitian ini adalah tulisan-tulisan yanag memang membahas mengenai 'iddah dan teori double movement.

Kedua, dalam mencari jawaban yang akan disajikan dalam penelitian, diperlukana

3 Abdul Mustaqim, Metode penelitian alQur'an dan Tafsir, (Yogyakarta: Idea Pres, 2015), hlm. 109.

${ }^{4}$ Puji Lestari, Al-Qur'an dan Pennyembuhan Studi Living Qur'an tentang Praktek Pennyembuhan Alternatif Bengkel Manugso di Jalan Kelurahan Pedurungan Tengah Kecamatan Pedurungan Semarang, Skripsi (Semarang : UIN Walisongo, 2018), hlm. 22. sebuah metode analisis. Metode analisis yang digunakan adalah berupa deskriptifanalisis. Deskriptif-analisis adalah memaparkan tentang apa yang dimaksud dengn teori double movement dan 'iddah. Selanjutnya, dari pemaparan tersebut dilakukan yang namanya analisa terhadap dalil yang menjelaskan mengenai 'iddah. Analisa yang dimaksud adalah menganalisis ayat tentang 'iddah untuk dijadikan hukum dan diterapkan kepada laki-laki dengan menggunkan teori double movement.

\section{TEORI DOUBLE MOVEMENT}

\section{Pencetus Teori Double Movement}

Orang yang pertama kali memperkenalkan cara memahami alQur'an yang berbasis pada kajian hermeneutika dengan penyebutan teori double movement (gerakan ganda) adalah Fazlur Rahman. Teori yang dibawa oleh Rahman ini adalah teori yang tergolong pada teori yang digunakan untuk memahami suatu ayat al-Qur'an.

Fazlur Rahman adalah ulama' yang lahir negara bagian Timur Tengah. Beliau lahir di Pakistan pada hari Minggu tanggal 21 September 1919. Letak pasti Rahman dilahirkan adalah di daerah yang bernma Hazara. Hazara terletak di negara Pakistan bagian barat laut. Tempat ini adalah tempat yang memang melahirkan banyak pemikirpemikir yang hebat. Diantara pemikir yang lahir di tempat ini adalah Syah Waliyullah al-Dahlawi, Sayyid Khan, Amir Alidan dan M. Iqbal. Dari berbagai pemikir inilah yang menjadikan Rahman mewarisi jiwa pemikir kritis yang nantinya disebut sebgai seorang pemikir yang berfaham neo-modernis. ${ }^{5}$

Kondisi sosial masyarakat Pakistan saat Fazlur Rahman lahir, ketika terjadi perdebaatan publik diantra tiga kelompok yang tengah

${ }^{5}$ Sibawaihi, Hermeneutika al-Qur'an Fazlur Rahman, (Yogyakarta : Jalasutra, 2007), hlm. 17. 
bersiteru. Diantara kelompok yang tengah bersiteru adalah kelompok modernis, tradisionalis dan fundamentalis. Antara kelompok satu dengan kelompok lain saling mengklaim kebenaran yang dibawa oleh kelomoknya. Hal inilah yang menjadikan ketidak seimbangan dalam masyarakat. Perdebatan antara tiga kelompok tersebut semakin memanas ketika Pakistan yang awalnya suatu daerah yang termasuk dari bagian negara India memisahkan diri dan menjadi negara yang mempunyai sistem pemerintahan sendiri. Pakistan menjadi negara yang berdaulat dan merdeka pada tanggal 14 Agustus $1947 .^{6}$

Salah satu yang menjadi perdebatan ketiga kelompok pengusung kemerdekaan Pakistan adalah bagaimana sistem yang akan diterapkan pada Paksitan pasca berdaulat dari negara India. Ketiga kelompok tersebut membawa ideologi masing-masing. Kelompok modernis merumuskan konsep kenegaraan Islam dalam bingkai term-term ideologi yang berdasakan pemahaman moderen. Kelompok tradisionalis menawarkan sistem kenegaraan yang sama dengan kekhalifaan Islam dulu. Yakni, berbentuk khalifah dan Imamah. Sedangkan kelompok fundamentalis mengusulkan konsep kenegaraan "kerajaan Tuhan". perdebatan ini berlanjut sampai melahirkan sesuatu yang berbuah konstitusi dengan amandemennya. ${ }^{7}$

Dari perdebatan inilah, kelak Fazlur Rahman menanggapi dan mengusulkan gagasan yang disebut dengan neo-modernis. Neo-modernis adalah penamaan aliran atau gerakan. Istilah ini secara sederhana dapat

\footnotetext{
${ }^{6}$ Sibawaihi, Hermeneutika al-Qur'an Fazlur

Rahman, (Yogyakarta : Jalasutra, 2007), hlm. 17.

${ }^{7}$ Sibawaihi, Hermeneutika al-Qur'an Fazlur Rahman, (Yogyakarta : Jalasutra, 2007), hlm. 17.
}

diartikan dengan "paham modernisme baru", neo-modernis digunakan untuk memberi identitas pada kecenderungan pemikir Islam yang muncul dalam dekade terakhir yang berusaha menjembatani bahkan mengatasi pemikiran tradisionalisme dan modernisme. Artinya, jika modernisme sangat kongkrin terhadap rasionalisme, neo-modernism mencoba mengambil apa yang ditinggal oleh gerakan modernisme. Disamping itu, kemunculan neo-modernis karena tuntutan zaman yang kurang mendapat antisipasi oleh pemikiran keislaman yang sudah mapan secara historis. ${ }^{8}$

Fazlur Rahman mengusalkan konsep ini kepada Pemikir Pakistan ketika Pemerintahan dibawah kekuasaan Ayyub Khan yang corak berpikirnya condong pada pemikiran yang modern. Pada pemerintahan ini Rahman ditunjuk sebagai direktur Pusat Lembaga Riset Islam selama satu priode dan juga menjabat sebagai Dewan Penasihat Ideologi Islam. ${ }^{9}$

Di masa ini juga, Rahman menjadi salah seorang yang memprakarsai terbitnya jurnal Journal of Islamic Studies, sebagai wadah yanag menampung gagasan-gagasannya yang sangat mengangkat akan pemikiran Islam yang berfaham modernisme.

Kepercayaan yang diberikan dalam beberapa jabatan, Rahman teleh menjadikannya sebagai ladang untuk menuangkan pemikiranya yang berilian. Rahman memanfaatkan peluang emas ini untuk memerkenalkan gagasangagasan dengan menafsirkan kembali Islam untuk menjawab tantanagantantangan pada masa itu kepada umat

${ }^{8}$ Amir Aziz, Neo-Modernisme Islam di Indonesia, (Jakarta : Rieneka Cipta, 1999), hlm 1516.

9 Taufik Adnana Amal, Islam dan Tantanga Modernitas : Studi Atas Pemikiran Hukum Fazlur Rahman, (Bandung : Mizan, 1996), hlm. 13. 
Islam khususnya yang tinggal di negara Pakistan. ${ }^{10}$

Pemikiran yang dituanagkan oleh Rahman dalam bentuk gagasan penafsiran Islam tidak luput dari pertentangan dari kelompok tradisionalis dan fundamentalis. Puncak meletusnya pertentangan terhadap gagasannya Rahman adalah ketika dia menerbitkan bukunya yang berjudul Islam. Dalam dua bab pertama dia menjelaskan bahwa al-Qur'an secara keseluruhan adalah kalam Allah dan dalam pengertian biasa, juga seluruhnya adalah perkataan Muhammad. ${ }^{11}$

Pada tahun 1982 Fazlur Rahman kembali mengeluarkan buak pemikiranya dalam bentuk buku yang berjuduli "Islam and modernity : Tanformasi of Intllectual Tradision". Dalam buku inilah dia memperkenalkan konsep double movement dalam menafsirkan al-Qur'an. ${ }^{12}$

\section{Epistimologi Teori Double Movement}

Latar belakang Rahman mengemukakan buah pemikirannya dalam bentuk teori double movement adalah karena dia menginginkana gagasan untuk menjadikan al-Qur'an bersifat universalitas dan fleksibel. Karena, bila al-Qur'an hanya sebatas teks biasa, al-Qur'an tidak akan bisa dipahami secara atomistik. Cara memahami al-Qur'an haruslah menyatu padukan suatu yang berjalan berkelindan sehingga menghasilkan suatu weltanschauung yang pasti. ${ }^{13}$

10 Taufik Adnana Amal, Islam dan Tantanga Modernitas: Studi Atas Pemikiran Hukum Fazlur Rahman, (Bandung: Mizan, 1996), hlm. 13.

11 Taufik Adnana Amal, Islam dan Tantanga Modernitas: Studi Atas Pemikiran Hukum Fazlur Rahman, (Bandung: Mizan, 1996), hlm. 14.

12 Kurdi, dkk, Hemeneutika al-Quran \& Hadis: Hermeneutika al-Qur'an Fazlur Rahman (Teori double Movment), (Yogyakarta: Elaq Press, 2010), hlm. 67.

${ }^{13}$ Kurdi, dkk, Hemeneutika al-Quran \& Hadis: Hermeneutika al-Qur'an Fazlur Rahman (Teori
Pemahaman yang seperti inilah yanag nantinya tidak akan didapatkan dalam penafsiran yang berbasis faham klasik. Menurut Fazlur Rahman para mufsir klasik terlalu asik dengan penafsiran yang memahami bahasa saja. Penafsiran yang hanya penafsirkan secara bahasa akan menyebabkan para mufasir terjebak dalam penafsiran yang literal-tekstual. Bagi Rahman fenomena penafsiran yang demikian, dikarenakan ketidaktepatan dan ketidaksempurnaan alat-alat atau metode-metode dalam menafsirkan al-Qur'an. ${ }^{14}$

Dari kegelisahan yang demikian Fazlur Rahman menawarkan sebuah metode yang logis, kritis dan komperhensif, yaitu hermeneutika double movement (gerak ganda interpretasi). Dengan menggunakan metode ini Rahman berharap bisa memeberikan pemahaman yang sistematis dan kontekstualis. Sehingga bila seseorang yang akan menafsirkan al-Qur'an menggunkan metode ini tidak akan menghasilkan penafsiran yang atomistik, literalis dan tekstualis. Melainkan dengan bantuan metode penafsiran yang diberikan oleh Rahman dapat membantu para mufasir untu menjawab persoalan-persoalan yang kekinian. ${ }^{15}$

Adapun cara hermeneutika double movement yang digagas oleh Fazlur Rahman dalam menafsirkan alQur'an adalah sebagai berikut:

Peratama, gerak pertama. Gerak ini yakni dari situasisekarang ke masa al-Qur'an dituruankan, terdiri dari dua langkah

double Movment), (Yogyakarta: Elaq Press, 2010), hlm. 66.

${ }^{14}$ Kurdi, dkk, Hemeneutika al-Quran \& Hadis: Hermeneutika al-Qur'an Fazlur Rahman (Teori double Movment), (Yogyakarta: Elaq Press, 2010), hlm. 66-67.

${ }^{15}$ Kurdi, dkk, Hemeneutika al-Quran \& Hadis: Hermeneutika al-Qur'an Fazlur Rahman (Teori double Movment), (Yogyakarta : Elaq Press, 2010), hIm. 67. 
a. Langkah pertama merupakan tahap pemahaman arti atau makna dari suatu pernyataan dengan mengkaji situasi atau problem historis, dimana pernyataan al-Qur'an tersebut menjawabnya. Tentu saja, sebelum mengkaji ayat-ayat alQur'an yang bersifat spesifik dalam sinaran situasi-situasi spesifikasinya perlu mengkaji tentang situasi makro dalam batasan-batasan masyarakat agama, adat istiadat, lembaga-lembaga bahkan mengenai kehidupan masyarakat Arab pada saat alQur'an yang menjadi pedoman agama Islam diturunkan. Bahkan, pada kebiasaan atau tradisi yanag dilakukan oleh masyarakat Mekkah. ${ }^{16}$ Jadi, langkah pertama dari gerakan pertama adalah memahami makna al-Qur'an sebagai suatu kesatuan yang menyeluruh, yang mana dalam memahami ini diperlukanya memahami tradisi orang Arab sdat. suatu ayat itu diturunkan.

b. Langkah

kedua, menggeneralisasikan jawabanjawaban spesifik itu dan menyatukan sebagai pernyataanpernyataan yang memiliki tujuantujuan moral-sosial umum yang dapat disaring dari teks-teks yanag sifatnya spesifik dalam sinaran latar belakang sosio historis dan rasio legis ('ilat hukum) yang sering dinyatakan. ${ }^{17}$ Langkah kedua ini adalah hasil dari langkah pertama yakni berupa ditemukannya sebuah 'ilat atau alasan ditetapkannya suatu hukum.

16 Fazlur Rahman, Islam and Modernity; Tranformation of an Intllectual tradition, (Chichago: Uinversity Press, 1982), hlm. 7.

17 Fazlur Rahman, Islam and Modernity; Tranformation of an Intllectual tradition, (Chichago: Uinversity Press, 1982), hlm. 7.
Kedua, gerakan kedua ini merupakan suatu proses yang bermula dari pandangan umum ke pandangan khusus, lalu dirumuskan untuk direalisasikan dan diterapkan pada zaman sekarang. Pandangan umum yang dimaksud dalam hal ini adalah proses pembacaan yang telah dilakukan pada gerakan pertama dan telah menemukan dasar penentuan suatu hukum ('ilat). Selanjutnya, pengertian dari pandangan khusus ini adalah hasil dari perumusan tersebut. ${ }^{18}$

Dengan demikian, metodologi yang diintrodusir oleh Rahman adalah metode berfikir yang bersifat reflektif, mondar-mandir antr deduksi dan induksi secara timbal balik. Metodologi semacam ini tentu saja akan mebawa implikasi, bahwa yang nmany hukum Allah dalam pengertian seperti yang dipahami oleh manusia itu tidak ada yang abadi. Yang ada dan abadi hanyalah prinsip moral.

\section{Pengertian dan Ayat 'Iddah}

Makna 'iddah secara bahasa berasal dari kata al-'adad. Sedangkan, kata al'adad merupakan bentuk mashdar dari kata kerja 'adda-ya'uddu, yang artinya menghitung. Sedangkan secara terminology, arti 'iddah adalah masa menunggu wanita untuk melakuakan perkawinan setelah teradinya perceraian dengan suaminya, baik bentuk dari cerai tersebut adalah cerai hidup maupun dengan cerai mati dengan tujuan untuk mengetahui keadaan rahim dari seorang istri tersebut atau juga ditujukan kepada sang suami untuk berfikir kembali tentang tindakan yang dilakukan untuk menceraikan istrinya. ${ }^{19}$

Sedangkan pengertian 'iddah dari sudut pandang ulama' fiqih, memiliki

18 Fazlur Rahman, Islam and Modernity; Tranformation of an Intllectual tradition, (Chichago: Uinversity Press, 1982), hlm. 8.

${ }^{19}$ Harun Nasutio, Ensiklopedia Islam, (Jakarta: Ichtiar Van Hoeve, 1999), hlm. 637. 
beragam pengertian, akan tetapi, memiliki maksud yang sama. Adapun beberapa ulama' yang menjelasakan definisi 'iddah adalah sebagai berikut:

1. Menurut Wahbah al-Zuhaili, 'iddah merupakan masa penantian bagi seorang perempuan untuk memastikan keadaan rahimnya dalam keadaan kosong dari kandungan atau sebagai bentuk ungkapan kesedihan istri atas perepisahannya dengan suami. ${ }^{20}$

2. Menurut Sayyid Sabiq, iddah adalah masa tunggu yang menunjukan masa penantian dan penolakan seorang wanita untuk menikah lagi setelah ditinggal mati suami akibat perceraian atau sebab meninggal dunia. ${ }^{21}$

3. Menurut as-San'ani 'iddah adalah nama bagi suatu masa yang mana seorang wanita diharuskan untuk menunggu dan dalam masa itu diperuntukana agar wanita bisa melakukan pernikahan lagi yang dikarenakan wanita telah berpisah dari suaminya akibat ditinggal mati atau diceraikan. $^{22}$

4. Menurut as-Subki, 'iddah adalah sesuatu yang dilakukan oleh perempuan untuk menghitung beberepa hari atau masa dalam penantian. Tidak sebatas pada penghitungan masa penantian, 'iddah juga adalah suatu nama untuk masa bagi perempuan untuk menunggu dan mencegahnya dalam melakukan pernikhan lagi setelah diceraikan oleh suaminya atau ditinggal mati suaminya. ${ }^{23}$

20 Wahbah Zuhaili, al-Fiqh al-Islami wa Adillatuhu, ed. In, Fiqih Islam: Pernikahan, Talak, Khulu', meng-lla' Isteri, Li'an, Zihar, Masa 'Iddah, Terj. Abdul Hayyie al-Hattani, dkk, jilid 9, (Jakarta: Gema Insani, 2011), hIm 535.

${ }^{21}$ Sayyid Sabiq, Fiqih Sunnh, Terj. Asep Sobari, dkk, jilid 2, (Jakarta: al-l'tishom, 2013), hlm. 513.

${ }^{22}$ Amir Syarifuddin, Hukum Perkawinan Islam di Indonesia: Antara Fiqih Muamalat dan Undangundang Perkawinan, (Jakarta: Kencana Pernada Media Group, 2009), hlm 304.

23 Ali Yusuf, as-Subki, Nizam al-Usra fi alIslam, ed. In. Fiqih Keluarga, terj. Nur Khozin, (Jakarta: Amzah, 2010), hlm. 348.
5. Menurut mazhab Hanafiyah, 'iddah adalah masa yang ditentukan oleh syar' $i$ untuk menghilangkan jejak pernikahan sebelumnya. Menurut mazhab Malikiyah, 'iddah adalah masa larangan untuk menikah bagi perempuan pasca ditalak, wafatnya suami, atau terjadi faskh pernikahan. ${ }^{24}$

Pemeberlakuan 'iddah pada masa dimana ketika ada seorang pasangan suami istri yang telah berpisah, baik perpisahan itu dari kehendak keduanya yang melahirkan sebuah perceraian atau juga akibat suami telah meninggal dunia. Jika masa iddah akibat sebuah perceraian, maka, adanya masa 'iddah diharapkan baik suami maupun istri memfikirkan kembali perceraian tersebut agar bisa kembali ruju'.

Jadi, yang dimaksud dengan 'iddah adalah masa dimana seorang perempuan dilarang untuk melakuakan perkawinan setelah berpisahnya dengan suami, baik itu akibat perceraian atau ditinggalnya suami kerana telah meninggal dunia. Penetapan masa 'iddah yang dilakukan oleh perempuan sesuai dengan yang ditentukan syara', dengan tujuan agar perempuan tersebut bisa memastikan kondisi rahim perempuan benar-benar kosong dari suaminya atau juga bertujuan untuk memberikan ruang berfikir untuk laki-laki melakuakan inisiatif baik agar melakukan ruju' agar perceraian tersebut tidak terjadi.

Masa iddah yang dilakukan oleh perempuan ada lima macam menurut alQur'an dan satu masa 'iddah yang masih menjadi perdebatan ulama'. Diantara masa 'iddah yang dijelaskan dalam al-Qur'an adalah sebagai berikut:

1. Wanita yang ditalak masa 'iddah-nya tiga kali quru' atau tiga kali sucian.

2. Wanita yang bercerai dengan suami tapi belum melakukan hubungna suami istri tidak ada masa 'iddah untuknya.

24 Deza Emira, Komparasi Analisis Maqasid Syariah dan Kesetaraan Gender Tentang Hukum 'Iddah, skaripsi (Jakarta: UIN Syarif Hidayatullah, 2016), hlm 19-20. 
3. Masa 'iddah untuk wanita yang hamil adalah sampai melahirkan.

4. Masa 'iddah untuk wanita yang ditinggal mati suaminya adalah empat bulan sepuluh hari.

5. Masa 'iddah untuk wanita yang sudah menopasuse atau sudah tidak mengalamai haid adalah tiga bulan.

Sedangkan 'iddah untuk wanita yang bercerai akibat gugatan oleh wanita atau yang disebut dengan hulu' ulama' berbeda pendapat. Pertama, masa 'iddah-nya adalah sama dengan wnita normal yang diceraikan suaminya yakni tiga quru'. Kedua, masa 'iddah-nya adalah hanya satu kali sucian bukanaa tiga kali sucian. Dari kedua pendapat tersebut saling memiliki dasar yang kuat untuk menghukumi masa 'iddah untuk wanita yang menggugat cerai pada suami. $^{25}$

Ayat-ayat al-Qur'an yang menjelaskan tentang tema 'iddah ada delapan ayat yang terbagi dalam tiga surat. Yakni terdapat pada al-Ahzab ayat 29, atTalaq ayat 1, 4. 6 dan 7 dam pada surat alBaqarah ayat 228, 232 dan $234 .{ }^{26}$ Ayat yang menjelaskan wanita harus menjalankan 'iddah selama tiga kali quru' ialah pada:

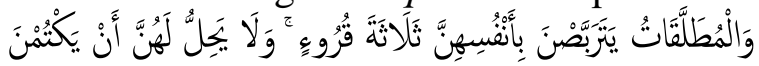

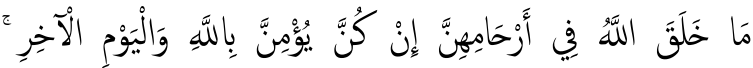

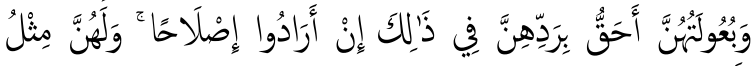

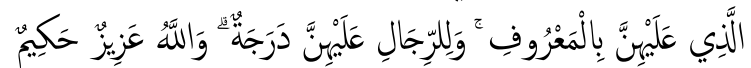

"Wanita-wanita yang ditalak handaklah menahan diri (menunggu) tiga kali quru'. Tidak boleh mereka menyembunyikan apa yang diciptakan Allah dalam rahimnya, jika mereka beriman kepada Allah dan hari akhirat. Dan suamisuaminya berhak merujukinya dalam masa menanti itu, jika mereka (para suami) menghendaki ishlah. Dan para wanita

25 Ria Noviani, Pandangan Ibnu Qayyim Tentang 'Iddah hulu', Skripsi, (Banda Aceh: UIN ArRaniry Darussalam, 2017), hlm. 33.

26 Ahmad Muhammad Yusuf, Ensiklopdi Tematis Ayat al-Qur'an \& Hadits, (Jakarta: Widya Cahaya, 2009), hlm. 327. mempunyai hak yang seimbang dengan kewajibannya menurut cara yang ma'ruf. Akan tetapi para suami, mempunyai satu tingkatan ke lebihan daripada isterinya. Dan Allah Maha Perkasa lagi Maha Bijaksana." (Q.S al-Baqarah: 228).

Dari keterangan ayat di atas bahwasanya untuk perempuan yang telah bercerai dengan suami harus melaksanakan 'iddah selama tiga quru'. Keterangan ayat di atas ditunjukan untuk wanita yang diceraikan sedang dalam keadaan normal, lalu ada beberapa ayat yang menerangkan masa 'iddah perempeuan dalam keadaan tertentu seperti perempuan yang diceraikan akan tetapi istri belum sempat digauli oleh suami tertera pada surat al-Ahzab ayat 49:

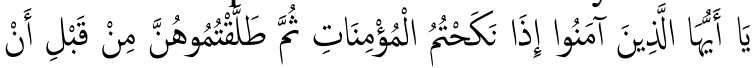

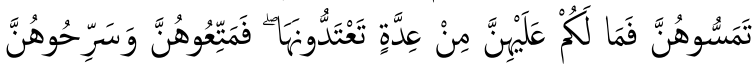
سَرَاحًا جَمِيلًا

"Hai orang-orang yang beriman, apabila kamu menikahi perempuanperempuan yang beriman, kemudian kamu ceraikan mereka sebelum kamu mencampurinya maka sekali-sekali tidak wajib atas mereka 'iddah bagimu yang kamu minta menyempurnakannya. Maka berilah mereka mut'ah dan lepaskanlah mereka itu dengan cara yang sebaikbaiknya." (Q.S. al-Ahzab: 49).

Masa 'iddah untuk wanita yang diceraikan sudah tidak mengalami haid atau disebut menopause yaitu selama tiga bulan dan wanita tersebut dalam kondisi hamil masa 'iddah yang dijalani yakni sampai anak yang dikandungnya lahir. Keterangn ini tertera pada surat at-Talaq ayat 4 :

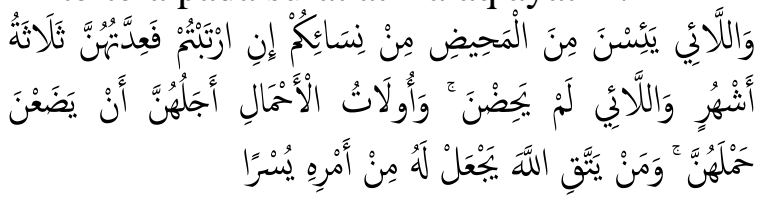

"Dan perempuan-perempuan yang tidak haid lagi (monopause) di antara perempuan-perempuanmu jika kamu raguragu (tentang masa iddahnya), maka masa iddah mereka adalah tiga bulan; dan begitu (pula) perempuan-perempuan yang tidak haid. Dan perempuan-perempuan yang 
hamil, waktu iddah mereka itu ialah sampai mereka melahirkan kandungannya. Dan barang -siapa yang bertakwa kepada Allah, niscaya Allah menjadikan baginya kemudahan dalam urusannya." (Q.S. atTalaq : 4)

Lalu, untuk wanita yang berpisah dari suaminya akibat suami telah meninggal dunia maka masa iddah-nya selama empat bulan sepuluh hari, ini tertera pada surat alBaqarah ayat 234:

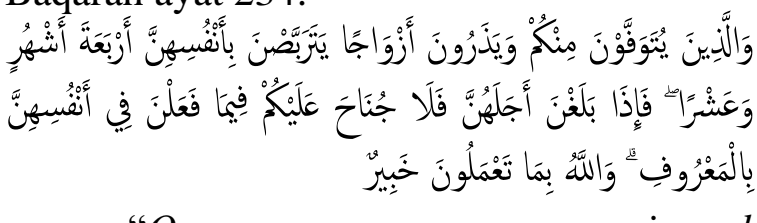

"Orang-orang yang meninggal dunia di antaramu dengan meninggalkan isteri-isteri (hendaklah para isteri itu) menangguhkan dirinya (ber'iddah) empat bulan sepuluh hari. Kemudian apabila telah habis 'iddahnya, maka tiada dosa bagimu (para wali) membiarkan mereka berbuat terhadap diri mereka menurut yang patut. Allah mengetahui apa yang kamu perbuat." (Q.S. al-Baqarah: 234).

\section{HASIL DAN PEMBAHASAN Penerapan Teori Double Movement pada Hukum 'Iddah Untuk Laki-Laki Asbab al-Nuzul}

Abdullah Saeed membagi asbab alnuzul menjadi dua definisi pokok. Pertama, asbab al-nuzul mikro, asbab al-nuzul ini menjelaskan peristiwa yang menyebabkan turunya suatu ayat, dimana ayat itu menjelaskan pandangan al-Qur'an tentang peristiwa yang telah terjadi lalu mengomentarinya dengan Allah menurunkan suatu ayat al-Qur'an.

Keuda, asbab al-nuzul makro, asbab al-nuzul ini menjelaskan peristiwa-peristiwa atau kebiasaan yang sudah ada. Kebiasaan ini bisa berupa laporan-laporan tentang bagaiamana oranag pada zaman tersebut memahami al-Qur'an baik sebelum maupuan sesudah turunya suatu ayat. ${ }^{27}$ adapun asbab al-nuzul-nya sebagai berikut:

${ }^{27}$ Abdullah Saeed, al-Qur'an Abad 21 : Tafsir Kontekstual, (Bandung : Mizan, 2015), hlm. 157.
1. Mikro

Sebab turunnya surat al-Baqarah ayat 228, Abu Dawud dan Ibnu Abi Hatim meriwayatkan dari Asma binti Yazid Ibnu as-Sakan al-Anshariyyah, dia berkata "Saya dicerai pada zaman Rasulullah dan ketika itu belum ditetapkan 'iddah untuk para wanita yang dicerai. Maka Allah menurunkan 'iddah untuk wanita-wanita yang dicerai, yaitu firman-Nya:

"Dan para istri yang diceraikan (wajib) menahan diri mereka (menunggu) tiga kali quru”

Ats-Tsa'labi, Hibatullah bin Salamah dalam kitab an-Naskh dan muqatil meriwayatkan bahwa pada masa Rasulullah, Isma'il bin Abdullah al-Ghifarimencerai istrinya, Qatilah, dia tidak tahu bahwa istrinya sedang hamil. Kemudian setelah beberapa waktu dia tahu baru tahu bahwa istrinya sedang hamil, maka diapun merujuknya kembali. Lalu istrinya tersebut melahirkan, namun anaknya meninggal dunia. Maka turunlah firman Allah:

"Dan para istri yang diceraikan (wajib) menahan diri mereka (menunggu) tiga kali quru",28

2. Makro

'Iddah untuk perempempuan telah muncul di Jazira Arab sebelum Islam datang. Praktik iddah yang dikerjakan oleh masyarakat pra-Islam bisa dikatakan cukup menyedihkan. Masyarakat Arab waktu itu mempunyai kebiasaan mewajibkan perempuan yang ditinggal mati suami dikurung di dalam ruang kecil selama setahun. Wanita tersebut tidak boleh memakai celak, wangi-wangian, dilarang menyentuh sesuatu, tidak oleh memotong kuku, tidak boleh menyisir rambut selama masa 'iddah. Secara fisik wanita tersebut terlihat sangat menyedihkan. Untuk membersihan kulitnya diberi

28 As-Suyuthi, Asbabun Nuzul: Sebab Turunnya Ayat Ayat Al Qur'an, (Jakarta : Gema sani, 2008), hlm. 97. 
seekor kambing untuk menggosoknya dengan kulitnya. ${ }^{29} \mathrm{Hal}$ ini terlihat pada kondisi sosio historis masyarakat Arab yang mana seperti yang dijelaskan pada hadits Nabi:

"Zainab berkata, bahwa ia perna mendengar ibunya, Ummu Salamah pernah bercerita, tentang seorang perempuan yang datang menemui Rasulullah SAW dan mengadukan masalahnya. Bahwa anak peremmpuan saya suaminya meninggal, dan mata anak saya sakit, bolehkah kami menggunakan celak. Nabi menjawab, tidak boleh, sebanyak tiga kali dengan jawaban yang sama, anakmu harus menjalani ihdad selama empat bulan sepuluh hari. Sungguh pada masa jahiliyah dilempar dengan kotoran unta selama setahun. Zainab berkata, bahwa pada masa jahiliyah, jika seorang perempuan ditinggal mati suaminya, maka perempuan tersebut tinggal di gubuk kecil, memakai pakainnya yang paling jelek, tidak memakai minyak wangi ataupun selama setahun kemudian didatangkan keledai, kambing dan burung. Setelah selesai masa 'iddahnya ia diperbolehkan keluar dengan syarat berdiri dipinggir jalan dan disuruh membuang kotoran hewan yang melewati jalan tersebut. Setelah itu perempuan diperbolehkan memakai minyak wangi lagi (menjalankan kehidupan seperti biasa). (HR, Bukhari Abu Daud, at- Tirmidzi dan Ibnu Majah).

Seperti yang telah disampaikan pada hadits di atas, bahwasanya masa 'iddah yang dilakukan oleh perempuan masyarakat jahiliyah cukup lama yakni selama satu tahun. Tidak hanya waktunya yang cukup lama, tapi, ruang gerak bagi perempuan juga terbatas.

29 Nuzulia Febri Hidayati, Tinjauan Gender Terhadap Konstruksi 'iddah dan Ihdad dalam kompilasi Hukum Islam, Tesis (Yogyakarta : Pasaca Sarjana UIN Sunan Kalijaga, 2018), hlm. 74.
Mereka ditempatkan pada sebuah tempat yang bisa dikatakan tidak layak untuk dihuni, pada sebuah gubuk kecil. Pakaian yang dipakai wanita yang sedang menjalankan masa 'iddah-nya juga harus berupa pakaian yang paling jelek yang dimiliki.

Untuk pasokan makanan memang cukup disediakan seperti seekor kambing. Lalu, tindakan terakhir yang harus dilakukan oleh wanita yang sedang melakukan iddah dan agar wanita tersebut bisa kembali menjalankan kehidupan normalanya, dia beridiri dipinggir jalan dan membuang kotoran dari hewan yang lewat di jalan yang wanita tersebut berdiri.

'Iddah yang dilakukan oleh wanita jahiliyah sangatlah menyedihkan, bahkan untuk dikatakan sebagai adat masyarakat terlalu mendisikriminasikan wanita. Meskipun ruang untuk wanita pada zaman itu sudah tidak mudah, ditambah dengan masa 'iddah maka ditambah dengan adanya masa 'iddah, maka bertambah berat hidup yang dijalani wanita pada masa itu. Barulah ketika Islam datang, budaya dan adat iddah yang demikian dihapus oleh Rasulullah dan diganti seperti pada ayat al-Qur'an yang telah dijelaskan di atas.

Islam memperbaruhi 'iddah yang dikerjakan oleh wanita yang telah berpisah dengan suaminya. Rasulullah tidak sepenuhnya menghilangkan apa saja yang harus dilakukan pada masa iddah. Semua yang harus dilakukan oleh wanita pada masa iddah dirubah kecuali, satu yakni untuk memakai wewangian. ${ }^{30}$ Pada waktu yang dikerjakan berubah yang awalnya 1 tahun menjadi, 4 bulan 10 hari. Wanita

30 Deza Emira Komparasi analisis Maqasid Syariah dan Kesetaraan Gender Tentag Huku 'Iddah, Skripsi (Jakarta : UIN Syarif Hidayatullah, 2016), HIm. 42-43. 
yang sedang 'iddah tidak harus mengurung disebuah gubuk kecil dan membersihkan kotoran hewan yang ada di jalan. Sedangkan, masa 'iddah yang harus dilakukan untuk wanita yang berpisah dengan suami akibat sebuah perceraian pada masyarakat Arab praIslam muncul sebuah kontroversi. Sebagian mengaktakan kalau wanita harus iddah setelah bercerai dengan suami dan sebagian yang lainnya mengatakan kalau wanita yang bercerai pada masyarakat pra-Islam tidak melakukan 'iddah. ${ }^{31}$

'Iddah pada zaman Nabi asalnya belum ada sesuai pada hadis yanag diriwayatkan oleh Sulaiman.

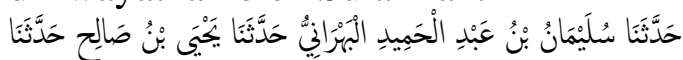

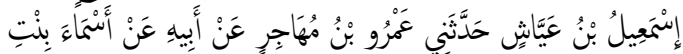

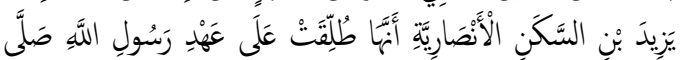

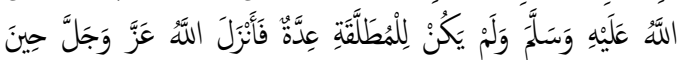

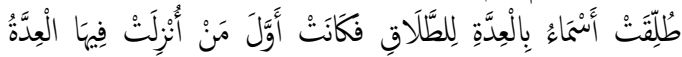
لِلْمُطَلََّّاتِ

"Telah menceritakan kepada kami Sulaiman bin Abdul Hamid AlBahrani, telah menceritakan kepada kami Yahya bin Shalih, telah menceritakan kepada kami Isma'il bin 'Ayyasy, telah menceritakan kepadaku 'Amr bin Muhajir dari ayahnya dari Asma binti Yazid bin As-Sakan AlAnshariyyah bahwa ia telah dicerai pada zaman Rasulullah shallallahu 'alaihi wasallam dan wanita yang dicerai tidak memiliki 'iddah, kemudian Allah 'azza wajalla menurunkan wahyu mengenai' iddah karena perceraian ketika Asma` dicerai, ia adalah wanita pertama yang karenanya diturunkan ayat tentang 'iddah wanita yang dicerai". (H.R. Sunan Abu Dawud: 1941).

Setelah adanya hukum untuk melakukan 'iddah bagi wanita ada

31 Nuzulia Febri Hidayati, Tinjauan Gender Terhadap Konstruksi 'iddah dan Ihdad dalam kompilasi Hukum Islam, Tesis (Yogyakarta : Pasaca Sarjana UIN Sunan Kalijaga, 2018), hlm. 74. bebebarapa masalah yakni, dimana wanita harus melaksakan iddah. Apakah harus dirumah mantan suami. Namun, dijawab oleh nabi bahwa wanita boleh melaksakan iddah ditempat selain rumah mantan suaminya. Sebagaimana hadis nabi :

"Telah menceritakan kepada kami Ishaq Telah menceritakan kepada kami Rauh Telah menceritakan kepada kami Syibl dari Ibnu Abu Najih dari Mujahid mengenai firman Allah :Dan orang-orang yang mati di antara kamu serta meninggalkan istri-istri (alBaqarah; 234). Ayat ini menerangkan wajibnya iddah di rumah keluarganya. Lalu Allah menurunkan ayat; Dan orang-orang yang akan mati di antara kami dan meninggalkan istri-istri, hendaklah membuat wasiat untuk istriistrinya yaitu nafkah sampai setahun tanpa mengeluarkannya dari rumah. Tetapi jika mereka keluar sendiri, maka tidak ada dosa bagimu mengenai apa yang mereka lakukan terhadap diri mereka sendiri dalam hal-hal yang baik. Mujahid berkata; Allah telah menjadikannya sebagai penyempurna dalam hitungan setahun yaitu tujuh bulan dan dua puluh malam sebagai wasiat. Apabila dia ingin, maka dia menempati sesuai wasiat tersebut. Namun jika ia ingin keluar, maka itu sudah menjadi kehendaknya. Itulah yang dimaksud firman Allah Ta'ala: Tetapi jika mereka keluar sendiri, maka tidak ada dosa bagimu. Maka Iddah adalah perkara yang wajib. Perawi mengaku itu dari Mujahid. Atha berkata; Ibnu Abbas berkata: "Ayat ini telah menghapus 'iddah di rumah keluarganya sehingga ia ber'iddah di tempat yang ia kehendaki, yaitu firman Allah Azza wa Jalla: 'Tanpa keluar rumah.' Atha berkata; 'Jika dia berkehendak, maka dia beriddah di rumah keluarganya dan tinggal sesuai wasiatnya.' Namun jika dia berkehendak, ia keluar darinya. Sebagaimana firman Allah Ta'ala: 
"Maka tidak ada dosa bagimu mengenai apa yang mereka lakukan terhadap diri mereka senidiri". (Q.S. alBaqarah: 240), Atha berkata; kemudian turun ayat mirats (mengenai warisan) yang menghapus mengenai tempat tinggal, maka dia boleh ber'iddah sesuai kehendaknya tanpa harus tinggal dirumahnya. Dan dari Muhammad bin Yusuf Telah menceritakan kepada kami Warqa dari Ibnu Abu Najih dari Mujahid dengan redaksi yang serupa. Dan dari Ibnu Abu Najih dari Atha dari Ibnu Abbas dia berkata; 'ayat ini telah menghapus 'iddahnya di rumah keluarganya sehingga ia ber'iddah di tempat yang ia kehendaki". (H.R. Shohih Bukhori: 4167)

Seiring dengan perkembangan zaman yang awalnya wanita bersifat pasif dalam rana sosial, pada zaman moderen wanita sudah bisa ikut berperan aktif di ranah sosial. Hal ini yang membuat sebuah dilema, apakah wanita harus tetap malukan iddah atau tidak harus melakukannya. Akan tetapi, dalam menjawab persoalan ini semua ulama' sepakat bahwa wanita yang berpisah dengan suami harus tetap menjalankan 'iddah sesuai dengan ketentuan syara'. Dengan tujuan mewajiban adanya 'iddah yakni untuk melihat kondisi Rahim dan menghormati laki-laki yang telah berpisah dengannya. ${ }^{32}$

\section{Kontekstualisasi ayat}

Dari ayat tersebut dikatakan bahwa wanita normal yang bukan menopause, hamil atau ditinggal mati suaminya harus melakukan 'iddah selama 3 quru' atau tiga kali sucian. Pada masa yang ditentukan alQur'an sudah bisa dikatakan bahwa untuk menentukan masa 'iddah membutukan aktifitas alami yang dialami organ tubuh

\footnotetext{
${ }^{32}$ Ahmad Muslimin, 'iddah dan ihdad wanita moderen, dalam Jurnal Mahkamah Vol. 2 No. 2, 2017, hlm. 228-230.
}

yakni keluarnya haid. Hal ini hanya dimiliki perempuan sedangkan untuk laki-laki tidak memilikinya.

Sedangkan untuk 'ilat

diberlakukannya iddah, ialah karena alasan memeriksa rahim perempuan masih kosoh atau sudah berisi dan memberikan waktu bagi suami untuk memikirkan kembali apakah akan menjalin hubungan kembali dengan istri atau tetap mantap dengan keputusannya untuk menceraikan istrinya. ${ }^{33}$ Meskipun 'ilat tersebut adalah yang paling banyak dijadikan dasar untuk melihat hukum diberlakukannya 'iddah untuk wanita yang telah berpisah dengan suami, tapi hal tersebut masih berbentuk kemungkinan bukan berupa kepastian. Karena, kalimat "Wanita-wanita yang ditalak handaklah menahan diri (menunggu) tiga kali quru'." Merupakan kalimat khabar dengan makna perintah. ${ }^{34}$

Lebih lanjut lagi untuk melihat apakah laki-laki harus melakuakan 'iddah di sini penulis paparkan apa tujuan diberlakuakannya masa 'iddah untuk wanita yang telah berpisah dengan suami pada masa Nabi: ${ }^{35}$

1. Untuk mengetahui kebersihan seorang perempuan, sehingga tercampur anatara keturunan seseoang dengan orang lain dan untuk memudahkan menentukan nasab antara suami yang lama atau yang baru.

2. Meringankan beban ekonomi perempuan yang dicerai (melalui nafkah yang diberikan oleh suami selama masa 'iddah).

33 Deza Emira, Komparasi Analisis Maqasid Syariah dan Kesetaraan Gender Tentang Hukum 'Iddah, skaripsi (Jakarta: UIN Syarif Hidayatullah, 2016), hlm 83-84.

34 Deza Emira, Komparasi Analisis Maqasid Syariah dan Kesetaraan Gender Tentang Hukum 'Iddah, skaripsi (Jakarta: UIN Syarif Hidayatullah, 2016), hlm. 82.

35 Sayyid Sabiq, Fiqih Sunnah, Jilid 8, Terj. Muhammad Thalib, (Bandung: al-Ma'arif, 2007), hlm. 140-141. Lihat juga Nuzulia Febri Hidayati, op. cit. hlm. 78-79. 
3. Mengurangi beban perempuan yang suaminya meninggal dengan mengurangi beban masa 'iddah menjadi empat bulan sepuluh hari.

4. Berkabung atas kematian suami untuk menghormati suami yang meningal, menjaga hak suami, serta menghargai perasaan pihak keluarga.

$$
\text { Selanjutnya hikmah dari }
$$
pemberlakukan 'iddah, selain melihat kekosongan rahim yakni untuk memberi kesempatan kepada pasangan untuk memikirkan kembali hubungan yang telah putus, menjunjung tingggi perkawinan dan menghormati pasangan. Semuanya bisa digolongkan tertuju pada laki-laki dan perempuan kecuali untuk kosongnya rahim yang khusus untuk perempuan. Hikmahikmah tersebut bila disandingkan dengan ilat yang bertujuan untuk memberi kesempatan agar bisa menjalin hubungan dengan istri maka akan sejalan dan bisa dijadikan dasar pemberlakuan iddah. Pernyataan demikian bisa menjadikan statemen baru bahwa laki-laki juga harus melakukan 'iddah dengan alasan, kalau setelah berpisah dengan suami, istri harus ber-'iddah agar suami mempunyai mempunyai kesempatan untuk mengurungkan niatnya menceraikan istri.

Setelah melihat 'ilat dan tujuan serta hikmah diberlakukannya iddah untuk perempuan yang telah berpisah dengan suami. Bisa dikatakan bahwa iddah hanya berlaku untuk perempuan, dengan melihat hal yang paling menonjol yakni kosongnya rahim perempuan. Keterangan ini sejalan dengan firman Allah :

$$
\text { "Apabila kamu menikahi }
$$

perempuan-perempuan yang beriman, kemudian kamu ceraikan mereka sebelum kamu mencampurinya maka sekali-sekali tidak wajib atas mereka 'iddah bagimu yang kamu minta menyempurnakannya."(Q.S alAhzab : 49).

Pada ayat ini menjelaskan bahwa bila suami istri belum melakukan hubungan intim sama sekali lau istri diceraikan maka tidak ada masa 'iddah untuk wanita tersebut. Hal ini mengindikasikan bahwa wanita yang belum melakukan hubungan intim, maka Rahim perempuan tersebut masih kosong.

Ada juga hadis nabi yang menerangkan tentang bagian masing-masing antara suami dan istri dalam masalah perceraian. Sebagaimana hadis Nabi:

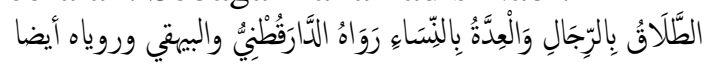

"Thalaq diperuntukan untuk lakilaki da 'iddah diperuntukan untuk perempuan. Hadis Riwayat ad-Darquthni dan Baihaqi"

Jadi, pada dasarnya pengkhususan iddah untuk perempuan Karen ada maqasid atas ayat yang menjelaskan iddah. Adapun, maqasidnya ialah untuk melihat kekosongan rahim pada perempuan dan memberikan waktu pada suami untuk berfikir ulang atas kasus perceraian yang telah ia alami.

\section{Bentuk 'Iddah Laki-laki}

Berdasarkan kontektualisasi dan masid pada ayat yang menerapkan tentang 'iddah, laki-laki tetap tidak bisa melakukan 'iddah. Hal ini disebabkan Karena seorang laki-laki tidak bisa melahirkan atau tidak mempunyai rahim yang menjadi salah satu maqasid diberlakukannya 'iddah untuk perempuan.

Tidak sebatas pada persoalan tersebut yang menajdi alasan laki-laki tidak melakukan 'iddah. Ketika wanita sedang menjalani 'iddah, sang mantan suami juga tetap harus memeberikan nafkah untuk sang istri. Meskipun, hal ini bisa dibantah dengan adanya wanita karier di zaman moderen ini.

'iddah hanya diberlakukan untuk perempuan memang itu sebuah hukum yanag sudah ditetapkan oleh Allah dan 'iddah dikategorikan sebagai suatu persoalan yang hukumnya mahdhoh. Hal ini sama halnya dengan hukum diharamnya daging babi. Bila di zaman moderen sudah ada alat yang bisa menghilangkan cacing pita yang ada pada daging babi. Adanya cacing pita merupakan salah satu maqasid yang ditemukan untuk menjadi alsan haramnya memakan daging babi. Alsan tetap dihukumi haram meskipun cacing pita yang ada pada daging babi bisa dikeluarkan 
dengan teknologi canggih adalah Karena, makan babi termasuk suatu perbuatan yang sifatnya mahdhoh.

Adapun untuk bentuk yang menyerupai 'iddah bisa dilakukan oleh lakilaki. Sebagaimana yang dijelaskan pada kita yang dikarang oleh wahbah Zuhaili:

"Apakah laki-laki memiliki 'iddah?, bagi laki-laki tidak ada 'iddah dalam arti istilah, maka setelah berpisah (dengan istrinya) boleh langsung menikah dengWW. perempuan lain, selagi tidak ditemukan larangan yang bersifat syar'i, seperti menikahi perempuan yang tidak halal dicampuri ketika masih mempunyai hubungan dengan isteri yanag pertama, dan kerabat yang masih menadi mahram seperti saudara perempuan, bibi dari bapak, bibi dari ibu, anak perempuan dari saudara laki-laki, anak perempuan dari saudara perempuan, walaupun melalui pernikahan yang fasad ataupun nikah yang subhat. Menikahi perempuan yang kelima pad amasa pertengahan masa iddah istri yang keempat, samapai berakhirnya masa 'iddah istri keempat yang di talak selesai. Menikahi perempuan yang telah ditalak tiga sebelum melakukan nikah tahlil". ${ }^{36}$

Dari penjelasan di atas meskipun dikatakan kalau laki-laki tidak melakukan iddah, tapi, ada beberapa sebab yang menjadikan laki-laki harus melakukan hal yang menyerupai 'iddah atau ulama' klasik menyebutnya dengan sebutan syibhul iddah. Diantara masa tunggu laki-laki untuk melakukan menikah lagi.

Pertama, jika seorang laki-laki menceraikan istrinya dengan talak raj' $i$, lalu dia ingin menikah dengan perempuan yang semahram dengan istrinya yang diceraikan, misalnya adik perempuan si istri, maka lakilaki tersebut tidak boleh menikahi adik perempempuan tersebut sebelum masa 'iddah yang dilakukan oleh istri yang dicereaikan selesai.

36 Wahbah Zuhaili, al-Figh al-Islami wa Adillatuhu, juz VII, (Damaskus: Dar alfikr, 1996), hlm. 627.
Kedua, jika seorang laki-laki memiliki empat istri, lalu dia menceraikan salah satu istrinya dan dia ingin menikah kdengan perempuan lain atau perempuan ke lima, maka dia harus menunggu masa 'iddah istri yang diceraikannya selesai. Baru setelah masa 'iddah istri yang diceraikan selesai, maka, diperbolehkan untuk menikah lagi.

\section{KESIMPULAN}

Dari berbagai penjelasan yang telah dipaparkan di atas menggunakan teori double movement untuk penerapan 'iddah pada laki-laki tidak bisa. Sebab, yang menjadi maqasid utama dalam diberlakukannya 'iddah untuk perempuana adalah Karena untuk melihat kekosongan rahim dari sang istri. Meskipun, hal ini bisa dibantah dengan bantuan teknologi moderen akan tetapi, 'iddah merupakan perbuatan yanag sifatnya mahdhoh.

Untuk pemberlakukan pada lelaki ulama klasik sudah membahasnya dengan penyebutan sibhul 'iddah. Dikatakan demikan karena, secara arti iddah tidak bisa diterapkan pada laki-laki, tapi ada suatu hal yanag bisa menjadikan laki-laki untuk melakukan masa tunggu untuk menikah lagi.

\section{DAFTAR PUSTAKA}

Amal, Taufik Adnana. 1996. Islam dan Tantanga Modernitas : Studi Atas Pemikiran Hukum Fazlur Rahman. Bandung : Mizan.

Aziz, Amir. 1999. Neo-Modernisme Islam di Indonesia. Jakarta: Rieneka Cipta.

Emira, Deza. 2016. Komparasi Analisis Maqasid Syariah dan Kesetaraan Gender Tentang Hukum 'Iddah. Skaripsi. Jakarta: UIN Syarif Hidayatullah.

Hidayati, Nuzulia Febri. 2018. Tinjauan Gender Terhadap Konstruksi 'iddah dan Ihdad dalam kompilasi Hukum Islam. Tesis. Yogyakarta: Pasaca Sarjana UIN Sunan Kalijaga. 
Kurdi, dkk. 2010. Hemeneutika al-Quran \& Hadis: Hermeneutika al-Qur'an Fazlur Rahman (Teori double Movment). Yogyakarta: Elaq Press.

Lestari, Puji. 2018. Al-Qur'an dan Pennyembuhan Studi Living Qur'an tentang Praktek Pennyembuhan Alternatif Bengkel Manugso di Jalan Kelurahan Pedurungan Tengah Kecamatan Pedurungan Semarang. Skripsi. Semarang : UIN Walisongo.

Muslimin, Ahmad. 2017. 'iddah dan ihdad wanita moderen, dalam Jurnal Mahkamah Vol. 2 No. 2.

Mustaqim, Abdul. 2015. Metode penelitian al-Qur'an dan Tafsir. Yogyakarta: Idea Pres.

Nasutio, Harun. 1999. Ensiklopedia Islam. Jakarta: Ichtiar Van Hoeve.

Noviani, Ria. 2017. Pandangan Ibnu Qayyim Tentang 'Iddah hulu'. Skripsi. Banda Aceh : UIN Ar-Raniry Darussalam.

Rahman, Fazlur. 1982. Islam and Modernity; Tranformation of an Intllectual tradition. Chichago: Uinversity Press.

Sabiq, Sayyid. 2007. Fiqih Sunnah. Jilid 8. Terj. Muhammad Thalib. Bandung : al-Ma'arif.

Sabiq, Sayyid. 2013. Fiqih Sunnh. jilid 2. Terj. Asep Sobari, dkk. Jakarta : alI'tishom.

Saeed, Abdullah. 2015. al-Qur'an Abad 21 : Tafsir Kontekstual. Bandung : Mizan.

Sibawaihi. 2007. Hermeneutika al-Qur'an Fazlur Rahman. Yogyakarta : Jalasutra.

Suyuthi, As. 2008. Asbabun Nuzul: Sebab Turunnya Ayat Ayat Al Qur'an. Jakarta: Gema sani.

Syarifuddin, Amir. 2009. Hukum Perkawinan Islam di Indonesia: Antara Fiqih Muamalat dan Undangundang Perkawinan. Jakarta: Kencana Pernada Media Group.

Wadud, Amina. 1994. Perempuan di dalam al-Qur'an. Bandung: Pustaka.
Yusuf, Ahmad Muhammad. 2009. Ensiklopdi Tematis Ayat al-Qur'an \& Hadits. Jakarta : Widya Cahaya.

Yusuf, Ali dan as-Subki. 2010. Nizam alUsra fi al-Islam, ed. In. Fiqih Keluarga, terj. Nur Khozin. Jakarta: Amzah.

Zuhaili, Wahbah. 2011. al-Fiqh al-Islami wa Adillatuhu, ed. In, Fiqih Islam : Pernikahan, Talak, Khulu', meng-Ila' Isteri, Li' an, Zihar, Masa 'Iddah. Terj. Abdul Hayyie al-Hattani, dkk. Jakarta: Gema Insani. 